\title{
Observations on the breeding of Indian long-billed vultures Gyps indicus at Gapernath, Chambal River in Rajasthan, India
}

\section{Chetan Misher ${ }^{1,2}$, Hemant Bajpai, ${ }^{1,3}$, Santosh Bhattarai, ${ }^{1,4}$, Prerna Sharma ${ }^{1}$, Rishi Sharma ${ }^{1}$ and Nirdesh Kumar ${ }^{1}$}

\author{
${ }^{1}$ Department of Wildlife Science, University of Kota, Rajasthan, India. \\ ${ }^{2}$ Ashoka Trust for Research in Ecology and the Environment, Bangalore, India \\ ${ }^{3}$ Bombay Natural History Society, Mumbai, India \\ ${ }^{4}$ National Trust for Nature Conservation, Biodiversity Conservation Center, \\ Ratnanagar-06, Sauraha, Chitwan -44204, Nepal \\ *Corresponding author chetanmisher@gmail.com
}

http://dx.doi.org/10.4314/vulnew.v72i1.2

\section{Introduction}

A sharp decline in south Asian vulture populations (>95\%) was first recorded in the late 90s in Bharatpur, India (Prakash 1999). This decline was reported to be most severe for three species of vulture: Oriental White-backed Vulture Gyps bengalensis, Long-billed Vulture Gyps indicus and Slender-billed Vulture Gyps tenuirostris (Prakash 1999, 2003; Gilbert 2003). Various hypotheses were proposed to explain the cause(s) of decline and the renal failure and avian gout found in many dead vultures that were examined (Pain 2001; Gilbert 2003). Eventually, a non-steroidal anti- inflammatory drug (NSAID) named diclofenac sodium was found to be highly correlated with numbers of dead vultures found in Pakistan's Punjab Province that died from renal failure and avian gout (Oakset al. 2004). Subsequent studies provided further evidence that diclofenac was the main cause of vulture mortality and population decline in south Asia (Green 2004, 2006). As a result, diclofenac was banned for veterinary use in India and other south Asian countries in order to protect depleted vulture populations. The positive effect of the ban on diclofenac was first reported in the form of gradually 
increasing populations of Longbilled Vultures in Pakistan (Chaudhary 2012) and a reduction in the rate of population decline of Gyps vultures in India and Nepal (Prakash 2012).

Of the nine species of vulture found in different habitats in India, seven occur in the western Indian state of Rajasthan (Naoroji 2007; Ali \& Ripley2007). Once commonly distributed, species such as Oriental White-backed, Long-billed and Slender-billed Vulture are now categorised as Critically Endangered on the IUCN Red List of Threatened Species, and are while provided highest legal protection in Schedule-I of Indian Wildlife Protection Act (WLPA), 1972.

The Long-billed Vulture, easily distinguished from Slender-billed Vultures by the former's relatively large size and long robust neck, is a cliff-nesting species (Naoroji 2007), although in the desert and grasslands of the Thar region in western India, they have been recorded nesting on trees (Kulshreshtha 2001). The breeding season for Long-billed Vultures is from October to May/June (Naoroji 2007) and, despite being a priority species for conservation, relatively little is known about their breeding and nesting ecology (Naoroji 2007). Here, we report information on the nesting ecology of Long-billed Vultures based on fortnightly monitoring of a nesting site at Gapernath, Chambal National Sanctuary, Kota, Rajasthan, India.

\section{Study Area}

The river Chambal is the only perennial river inthe western Indian state of Rajasthan. It originates from the state of Madhya Pradesh and runs north to the state of Uttar Pradesh via Rajasthan. A $225 \mathrm{~km}$ stretch of the river falls within Rajasthan and flows through seven districts: Kota, Bundi, Sawai-Madhopur, Chittorgarh, Karauli, Bhilwara, Tonk, Jhalawad, and Baran. The vegetation of the area consists of thorny forest, asubtype of the northern tropical forest (Champion \& Seth 1968).The study area falls within the boundary of Mukundra Hills Tiger Reserve, which contains species such as Leopard Panthera pardus, Sloth Bear Melursus ursinus, Striped Hyena Hyaena hyaena and Jackal Canis aureus. Gorges of river Chambal are home to a range of avian species including vultures and other raptors (Nair \& Krishna 2013). Four resident species of vulture exist: Egyptian Vulture Neophron percnopterus, Long-billed Vulture, Oriental White-backed Vulture and Red-headed Vulture Sarcogyps 
calvus. Migratory GriffonVultures Gyps fulvus have been observed in the area (Birdlife International 2017).The river Chambal and its surrounding forest patches is also a breeding area for Oriental Whitebacked Vultures and Red-headed Vultures (Chhangani, 2007). Our study site (Figure 1) is situated 23 $\mathrm{km}$ north of Kota city, near
Gapernath (N 2503'50.72”, E $75^{\circ} 43^{\prime} 09.22$ ") along an approximately one $\mathrm{km}$ of a "V"shaped gorge through which the river Chambal flows. This area contains breeding Long-billed Vultures on both sides of the gorge, as well as other raptors such as Bonelli's eagle Aquila fasciata and Indian Eagle Owl Bubo bengalensis.

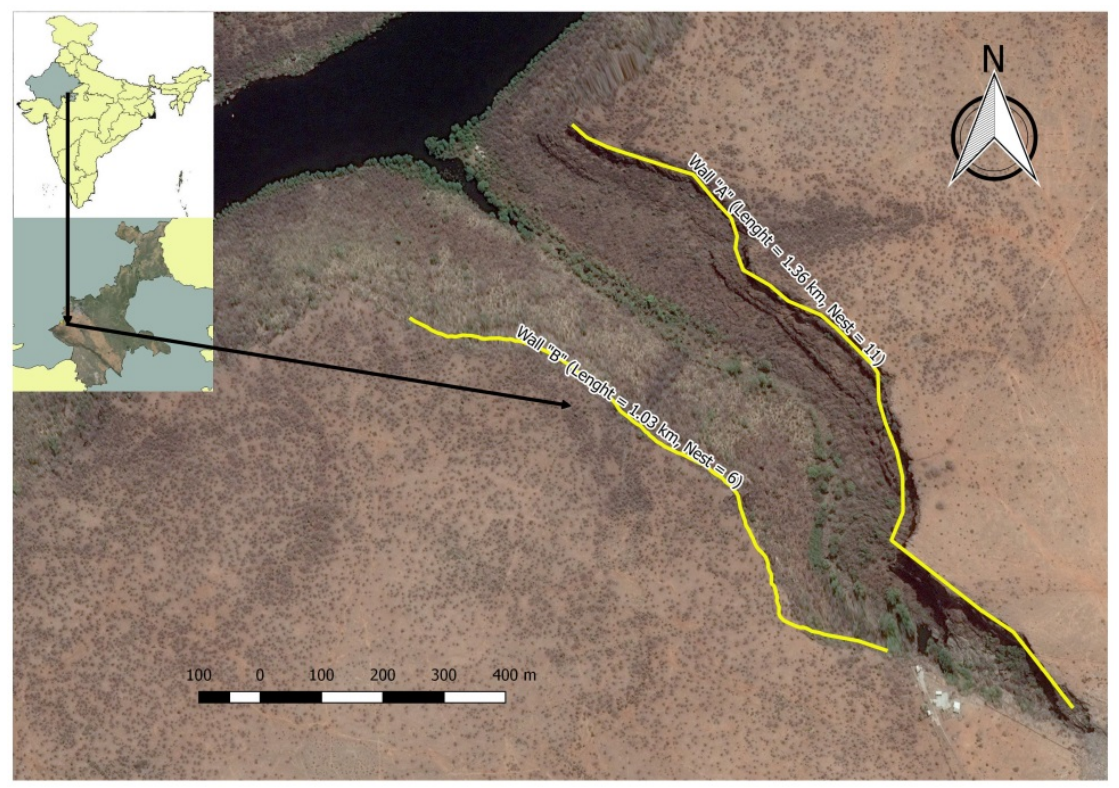

Figure 1: Location of Gapernath, Chambal River, Rajasthan. 


\section{Methods}

The study area was visited every fortnight between November 2012 and April $2013(\mathrm{n}=13)$ to monitor the nesting pattern of the vultures at Gapernath along the river Chambal. Two observers from each side of the gorge monitored the vultures and nests. On detection of a nest, its status was recorded (Table 1). Nests that contained an egg, an adult in an incubating posture and/or two adults were recorded as active. We considered nests with no eggs or unoccupied by vultures as inactive and excluded from observations. Based on the number of visits ( $\mathrm{n}=$ 13) nesting success from egg laying to fledgling was recorded. A follow up visit was also made during December 2014 to assess changes in the number of active nests in the Gapernath gorge. We used Bushnell 8x40 binoculars and Nikon Coolpix P510 (42X zoom) for regular observation and for photographic records respectively.

\section{Results and Discussion}

A total of twenty-one nests was recorded. Of these, seventeen nests were active (Table 1). All nests were found to be on cliffs. The first egg was observed on23 November 2012 while the first hatching was on 22 January2013.

Each nest was observed having only one egg, which was incubated continuously by either parent. Among the 17 active nests, successful hatching was observed in 16 nests. Thus we recorded hatching success as $94 \%$. One egg was observed to be abandoned by the birds after 29 days of incubation during December. We also observed mating attempts $(n=5)$ in adult birds during nestling period. Out of 16 chicks, one died at the hatching stage and one died during the fledgling stage, thus only 14 chicks fledged successfully with a success rate of $82.35 \%$. The incubation period was $62.5 \pm 1.5$ days and the overall nesting period was calculated as129.4 \pm 1.0 days.

The nest count survey during December 2014, recorded nine active nests of Long-billed Vultures in the same Gapernath gorge area. This $47.06 \%$ decline in nesting habitat use by the species could be due to disturbance by pilgrimage in the area. 


\begin{tabular}{|c|c|c|c|c|c|c|c|c|c|c|c|c|c|}
\hline \multirow{2}{*}{ Nest ID } & \multicolumn{4}{|c|}{ Year 2012} & \multicolumn{9}{|c|}{ Year 2013} \\
\hline & $23 / 11$ & $27 / 11$ & $02 / 12$ & $21 / 12$ & $13 / 01$ & $22 / 01$ & $10 / 02$ & $21 / 02$ & $22 / 02$ & $14 / 03$ & $18 / 03$ & $20 / 03$ & $05 / 04$ \\
\hline N1 & ICB & ICB & ICB & ICB & ICB & CHK & CHK & CHK & CHK & DEAD & DEAD & DEAD & DEAD \\
\hline N2 & ICB & ICB & ICB & ICB & ICB & CHK & CHK & CHK & CHK & CHK & CHK & CHK & FLY \\
\hline N3 & ICB & ICB & ICB & ICB & ICB & CHK & CHK & CHK & CHK & CHK & CHK & CHK & FLY \\
\hline N4 & ICB & ICB & ICB & ICB & ICB & CHK & CHK & CHK & CHK & CHK & CHK & CHK & FLY \\
\hline N5 & ICB & ICB & ICB & ABDN & ABDN & ABDN & ABDN & ABDN & ABDN & ABDN & ABDN & ABDN & ABDN \\
\hline N6 & ICB & ICB & ICB & ICB & ICB & CHK & CHK & CHK & CHK & CHK & CHK & CHK & FLY \\
\hline N7 & & ICB & ICB & ICB & ICB & CHK & CHK & CHK & CHK & CHK & CHK & CHK & FLY \\
\hline N8 & & ICB & ICB & ICB & ICB & CHK & CHK & CHK & CHK & CHK & CHK & CHK & FLY \\
\hline N9 & & ICB & ICB & ICB & ICB & CHK & CHK & CHK & CHK & CHK & CHK & CHK & FLY \\
\hline N10 & & ICB & ICB & ICB & ICB & CHK & CHK & CHK & CHK & CHK & CHK & CHK & FLY \\
\hline N11 & & ICB & ICB & ICB & ICB & CHK & CHK & CHK & CHK & CHK & CHK & CHK & FLY \\
\hline N12 & & & ICB & ICB & ICB & ICB & CHK & CHK & CHK & CHK & CHK & CHK & DEAD \\
\hline N13 & & & ICB & ICB & ICB & ICB & CHK & CHK & CHK & CHK & CHK & CHK & FLY \\
\hline N14 & & & ICB & ICB & ICB & ICB & CHK & CHK & CHK & CHK & CHK & CHK & FLY \\
\hline N15 & & & ICB & ICB & ICB & ICB & CHK & CHK & CHK & CHK & CHK & CHK & FLY \\
\hline N16 & & & ICB & ICB & ICB & ICB & CHK & CHK & CHK & CHK & CHK & CHK & FLY \\
\hline N17 & & & ICB & ICB & ICB & ICB & CHK & CHK & CHK & CHK & CHK & CHK & FLY \\
\hline
\end{tabular}

Table 1: Status of observed nests of Long-billed Vultures Gyps indicus near the river Chambal, Rajasthan, India, between 2012 and 2013. ICB - Incubating, ABDN - Abandoned, CHK - Chick, FLY - Chick fledged. 
Fourteen fledged birds in a year make this site a conservation priority as far as the survival of the species is concerned. Continuous monitoring of this site and along the entire Chambal River is necessary to collect information on population trends of the species, which can be crucial to propose conservation actions for this Critically Endangered species. Studies have shown several other sites with breeding colonies of Long-billed Vultures in different parts of the arid and semi-arid landscapes of Rajasthan (Chhangani 2004, 2009; Khatri 2015).We presume that more nesting colonies of Long-billed Vultures exist in the gorges along the river Chambal in Rajasthan and these need to be monitored on a priority basis as part of conservation efforts for this species in the area.

This preliminary data on nesting success of the species is of conservation significance to understand nature and extent of habitat use and decline rate of the species in and around study site. Detailed studies to get ecological insights of nesting habitat decline and anthropogenic effects on breeding pairs with effective monitoring tool is suggested for long term thrive of the long billed vultures in Geparnath, Rajasthan.

\section{Acknowledgements}

We thank Dr Fatima Sultana and Department of Wildlife Science, University of Kota, Rajasthan for providing equipment. Thanks to CCF and DFO, Mukundra Hills Tiger Reserve, Rajasthan for their support, Dr Partap Kataria and DrAnil Kumar Chhangani for their guidance and valuable inputs in the draft. We would also like to thank $\mathrm{Mr}$ Tapeshwar Singh Bhati for logistics and field work and anonymous reviewer for comments on this manuscript.

\section{References}

Ali, S. \& Ripley, S.D. 2007.Handbook of the Birds of India and Pakistan. Bombay Natural History Society and Oxford University Press.

BirdLife International.(2017. Important Bird Areas factsheet: National Chambal Wildlife Sanctuary (Bundi/Kota). Downloaded from http://www.birdlife.org on 13/05/2017. 
Champion, H.G. \& Seth, S. K. 1968. A Revised Survey of the Forest Types of India. Manager of Publication, New Delhi. 404pp.

Chaudhry, M. J. I.,Ogada, D., Malik, N.R.,Virani,M.Z.,and Giovanni, M.D. 2012.The first evidence that populations of the critically endangered Long-billed Vulture Gyps indicusin Pakistan have increased following the ban of the toxic veterinary drug diclofenac in South Asia. Bird Conservation International 22: 389-397

Chhangani, A. K. 2004.Status of a breeding population of Long-billed vulture (Gyps indicus) in and around Jodhpur (Rajasthan), India.Vulture News 50: 15-22.

Chhangani, A. K. 2007. Sighting and nesting site of a red-headed vulture, Sarcogypscalvus in Rajasthan, India. Indian Birds 3: 218-211.

Chhangani, A. K. 2009. Status of vulture population in Rajasthan, India. Indian Forester, 135 (2): 239-251.

Gilbert, M., Virani, M. Z., Watson, R. T., Oaks, J. L., Benson, P. C., Khan, A. A., Ahmed, S., Chaudry, J., Arshad, M., Mahmood, S. and Shah, Q. A. 2002. Breeding and mortality of Oriental White-backed Vulture Gyps bengalensisin Punjab Province, Pakistan.Bird Conservation International 12: 311-326.

Green R.E., Newton I., Shultz S., Cunningham A.A., Gilbert M., Pain, D. J. \& Prakash, V. 2004. Diclofenac poisoning as a cause of vulture population declines across the Indian subcontinent.Journal of Applied Ecology41: 793-800.

Green, R.E., Taggart, M.A., Das, D., Pain, D., Kumar, S.,Cunningham, A.A. and Cuthbert, R. 2006.Collapse of Asian Vulture Populations: Risk of Mortality from Residues of the VeterinaryDrug Diclofenac in Carcasses of Treated Cattle. Journal of Applied Ecology43: 949-956.

Khatri P.C. 2015. First nesting of critically endangered vulture in Bikaner: the nest site record of long-billed vulture (Gypsindicus) in kolayat tehsil, Bikaner. International Journal of Innovative Research and Review ISSN: 2347 - 4424 (Online)

Kulshreshtha, M. 2001.Long-billed VultureGyps indicus nesting on trees in the Thar Desert, Rajasthan.Journal of the Bombay Natural History Society983: 446-450. 
Nair, T. \& Krishna, Y. C..2013. Vertebrate fauna of the Chambal River Basin, with emphasis on the National Chambal Sanctuary, India. Journal of Threatened Taxa 5: 3620-3641

Naoroji, R. 2007. Birds of prey of Indian sub-continent. Om Books international, New Dehli.

Oaks J.L., Gilbert M,. Virani M. Z., Watson R. T., Meteyer C. U.,Rideout, B. A., Shivaprasad, H. L., Ahmed, S., Chaudhry, M. J. I., Arshad, M., Mahmood, S., Ali, A. \& Khan, A. A.. 2004. Diclofenac residues as the cause of vulture population decline in Pakistan. Nature 427: 630-633.

Pain, D. J. 2001.Conservation of critically endangered Gyps vultures in India.In L. Bennun\& Virani, M. Z. [Eds].Responding to the Asian vulture crisis: planning for vulture monitoring and conservation in Kenya. Proceedings and recommendations of a seminar and workshop held at the National Museums of Kenya, May 2001. National Museums of Kenya Ornithology Research Report 41, Nairobi.

Prakash V., Bishwakarma M. C., Chaudhary A., Cuthbert R. \&Dave R. 2012. The Population Decline of Gyps Vultures in India and Nepal Has Slowed since Veterinary Use of Diclofenac was Banned. PLoS ONE 7(11): e49118.

Prakash, V., Pain D. J, Cunningham A.A, Donald P.F. \&Prakash N. 2003.The catastrophic collapse of Indian White-backed Gyps bengalensis and Longbilled Gyps indicus vulture populations. Biological Conservation109: 381-390.

Prakash, V. 1999.Status of vultures in Keoladeo National Park, Bharatpur, Rajasthan with special reference to population crash in Gyps species. Journal of the Bombay Natural History Society 96: 365-378. 